NBER WORKING PAPER SERIES

\author{
GLOBAL MACROECONOMIC AND FINANCIAL SUPERVISION: \\ WHERE NEXT? \\ Charles Goodhart \\ Working Paper 17682 \\ http://www.nber.org/papers/w17682
}

\author{
NATIONAL BUREAU OF ECONOMIC RESEARCH \\ 1050 Massachusetts Avenue \\ Cambridge, MA 02138
}

December 2011

My thanks are due to Rosa Lastra, Alan Taylor and Adair Turner, for most helpful comments on this paper. The views expressed herein are those of the author and do not necessarily reflect the views of the National Bureau of Economic Research.

NBER working papers are circulated for discussion and comment purposes. They have not been peerreviewed or been subject to the review by the NBER Board of Directors that accompanies official NBER publications.

(C) 2011 by Charles Goodhart. All rights reserved. Short sections of text, not to exceed two paragraphs, may be quoted without explicit permission provided that full credit, including $(\mathbb{C}$ notice, is given to the source. 
Global Macroeconomic and Financial Supervision: Where Next?

Charles Goodhart

NBER Working Paper No. 17682

December 2011

JEL No. E32,E42,E44,F02,F21,F33,F34,F4,F42,F51

\begin{abstract}
$\underline{\text { ABSTRACT }}$
The overriding practical problem now is the tension between the global financial and market system and the national political and power structures. The main analytical short-coming lies in the failure to incorporate financial frictions, especially default, into our macro-economic models. Neither a move to a global sovereign authority, nor a reversion towards narrower economic nationalism, seems likely to take place in the near future. Meanwhile, the adjustment to economic imbalances remains asymmetric, with almost all the pressure on deficit countries. Almost by definition surplus countries are "virtuous". But current account surpluses have to be matched by net capital outflows. Such capital flows to weaker deficit countries have often had unattractive returns. A program to give earlier and greater warnings of the risks of investing in deficit countries could lead to earlier policy reaction, and reduce the risk of crisis.
\end{abstract}

Charles Goodhart

London School of Economics

caegoodhart@aol.com 


\title{
Global Macroeconomic and Financial Supervision: Where next?
}

\author{
By C.A.E. Goodhart
}

\section{Introduction}

There are two main problems to be faced in any attempt to improve the architecture of international macro-economic and financial oversight. The first is structural; the second is analytical. The first difficulty resides in the discord between having a system of national sovereignty at the same time as an international market economy, with a global financial and information technology framework, with largely free movement of goods and capital, though not yet of people. Political and military power remains at the nation state level, and separation between such nation states is much reinforced by countries generally having separate languages, cultures and legal systems.

The second main problem is one of analysis. Whereas we economists are generally comfortable in our analysis of real shocks, within a neo-Keynesian framework with wage/price stickiness tacked onto an otherwise real business cycle (RBC) (DSGE) model, and with a perfect frictionless financial system, we are much less assured when dealing with the analysis of models in which there are financial frictions, with an incomplete financial system, in which default, money and banks play an essential role.

Such complications often interact. Let me give two examples. First, the Basel Committee on Banking Supervision (BCBS) in its attempts to provide an international structure for banking regulation felt that it had no locus for imposing any (ladder of) sanctions for those banks transgressing their proposed ratios, since the imposition of sanctions/penalties was a national (not a 
supra-national) legal prerogative. ${ }^{1}$ As a result, their proposed capital, (CAR) ratios came to be treated as required minima (the word 'requirement' carries a lot of baggage), and to fall below such a required minimum could involve serious reputational risk. So, the available buffer for loss absorption became the much more exiguous margin which banks voluntarily held above the required minima.

Next, the question of 'Why did no one foresee this crisis?', as put by the Queen to an economist at LSE, (on the occasion of the ceremonial opening of a new academic building) (AFP: November 5 , 2008), was in part answerable by noting the relative weakness of the analysis of financial frictions, in the face of national insistence that all was satisfactory. Thus, many of the warnings about the dangers of excessive leverage, from Ragu Rajan at the IMF $(2005,2006)$, and from William White (2004, 2006), Claudio Borio (2007), and with W. White (2004), and with Philip Lowe $(2003,2004)$ at the BIS were laughed off, denied or ignored, and often comprehensively watered down by the national authorities involved. Nor was it, at the time, difficult to ignore such warnings. Not only are financial crises relatively rare tail events with a low frequency and unpredictable trigger, but also, according to Basel II and IFRS/GAAP accounting procedures, never in recent decades had the banking systems of developed countries seemed stronger, more profitable and better capitalised than in 2006/7, just before the crisis stuck. Markets completely concurred; CDS rates for major banks were then generally at an all-time low. We simply did not have the analytical power to demonstrate, over national objections, how objectively dangerous the context had become, though, as noted above, several economists working within the international supervisory authorities had perceived this.

\footnotetext{
1 This self-imposed constraint by the BCBS and Financial Stability Board (FSB) on their own actions is at long last being relaxed in the course of the Basel III negotiations, with any reduction in a bank's tier 1 core equity capital from $7 \%$ to the minimum of $4 \frac{1}{2} \%$ being met by the application of sanctions.
} 
Figure 1

\section{Average of 5 year CDS prices for $\mathbf{3 0}$ major global banks* \\ (New York Intra-Day Prices)}

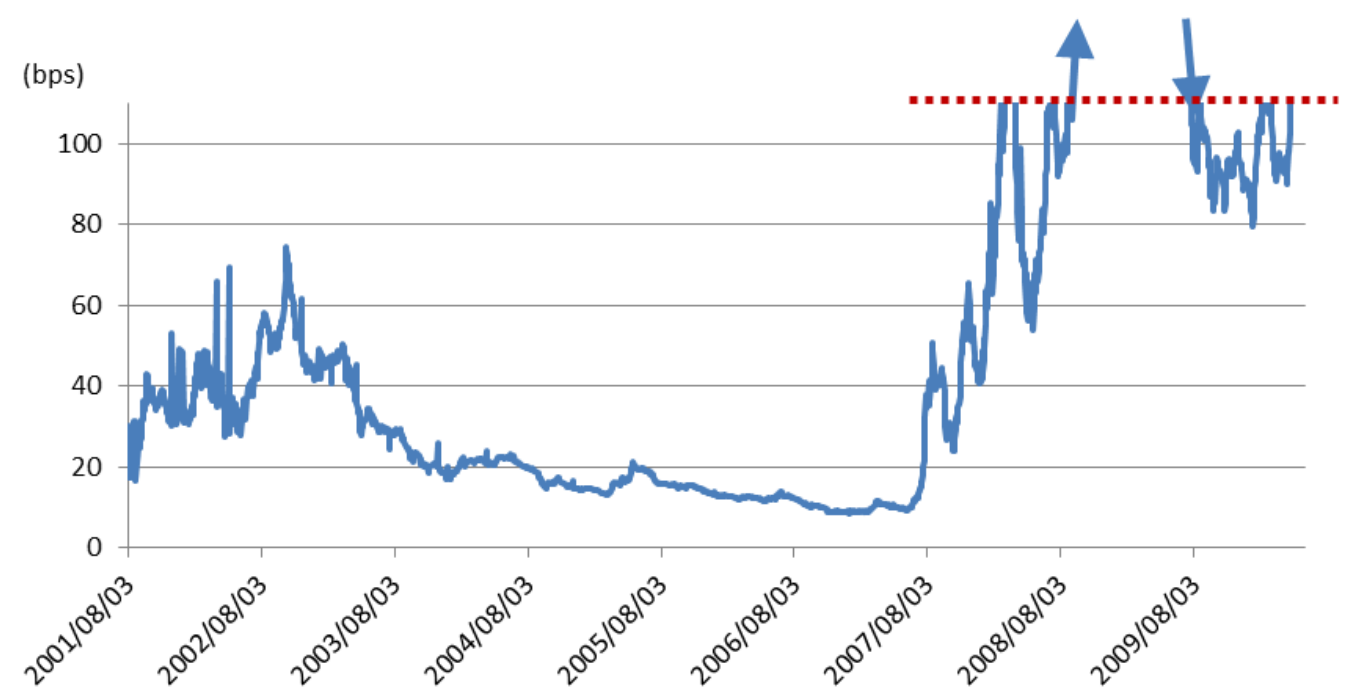

Source : Bloomberg

*30 major banks are American Express, BBVA, Banco Santander, JPMorgan, Bank of America, Wells Fargo, Citigroup, BNP Paribas, Societe Generale, Credit Suisse, Commerzbank, Deutsche Bank, Morgan Stanley, UBS, Goldman Sachs, Credit Agricole, HSBC Bank PLC, Barclays, ING, Lloyds TSB, RBS, Nomura, Standard Chartered PLC, Mitsubishi UFJ Financial, Intesa Sanpaolo SpA, Sumitomo Mitsui Banking, Mizuho Corporate Bank Ltd, Royal Bank of Canada, Macquarie Bank Ltd, UniCredit SpA

There is some chance that the current analytical short-comings of macro-finance may be rectified, somewhat. There is much less likelihood of any improvement to the deeper structural problem, whereby a global trading and financial system co-exists with national sovereignty over political and fiscal powers, separate legal structures, etc., etc.

There are, of course, two logical and comprehensive responses to this latter state of affairs. The first would be to transfer sovereignty and political (and other) powers to the global level, with each country abandoning sole control over its own affairs. Whereas from a utilitarian (or Rawlsian) 
viewpoint this would be both best and most efficient, it will not happen. The basic reasons are twofold. First, the major inequalities between countries mean that, in a democratic, one person one vote, world system, the inhabitants of the wealthy developed West would most likely lose out against the poorer, more populous South and East. The main opposition to a truly world democratic system will come from North America and Europe.

Second, fiscal and other redistribution within such a world system would shift resources from within

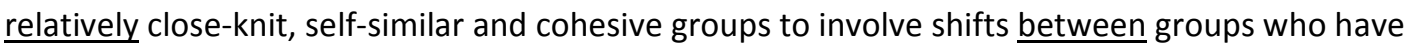
little in common and little personal contact. Even with the widening international horizons that IT can now bring, forcibly shifting resources from, say, Canadians to, say, Bangladeshis is not likely to be received happily in Toronto. The World, alas, is not (yet?) ready for a global, unified political system.

The second logical response, if one cannot transfer political power to the global level, is to make the trading and financial systems subject to national control, where the political power lies. The greatest loss in efficiency and generalised welfare from having national control relates to trade in goods, though even here the advantages of free trade (without national tariffs and subsidies) have not yet been accepted in agriculture, especially in basic foodstuffs. So, even within a world of separate nation states, most countries broadly adhere to a global system, managed and monitored by the WTO. And even under the extra pressure of the recent crisis, there was little evidence of backsliding on this front. Instead, concern about 'unfair' trading practices in goods has become transmuted into disputes about currency manipulation, whereby countries accuse each other of policies whose objective is to achieve competitive trading advantage.

We can, perhaps, picture a scale showing the relative concern of nations to retain control, rather than allowing global management, as follows:- 


\begin{tabular}{|l|l|l|l|}
\hline Moods & Movement of \\
\hline
\end{tabular}

At the extremes few currently advocate either re-imposing national controls over trade in goods or would seriously propose free global movement of persons. In between there is a general readiness to try to promote greater global freedom of services trade, at the same time as the Washington consensus on freedom of capital movement has come under greater attack. Meanwhile the recent adverse supply shocks in agriculture have underscored the primary responsibility of national authorities to feed their own people at acceptable prices, so the likelihood of any agreement of free trade in agriculture, whatever its long term overall welfare benefits, has probably receded yet further.

But this paper is macro/finance oriented, rather than having a macro/trade focus. So we will concentrate on the question of whether the global/national fault structure could be resolved by making the whole financial system more localised/national in character. This would be easy enough to do in practice. A first necessity would be to require all significant foreign-owned financial entities to establish themselves in each nation state as a nationally incorporated subsidiary, not a branch. New Zealand is, once again in (Central) banking practices, the exemplar. All its major banks are foreign (Australian) owned; the RBNZ has required all these subsidiaries to be so structured, e.g. with nationally separate IT and Treasury facilities, that, following the closure of the Australian headoffice, for whatever reason, the NZ subsidiary could be up and independently running the very next day. The disaster of the enforced closure of Lehman Bros International Europe (Lehman's London), or of Icesave, would not be such a disaster there, though there would still no doubt be problems, 
(e.g. in disentangling exactly where the claims on, or by, the separate parts of the failing Australian bank resided, notably if rehypothecation remains a common practice).

Many financial crises are transmitted from country to country, and sometimes triggered, by sudden surges, or 'stops', in international capital flows, e.g. Calvo et al. $(2006,2008)$ and Calvo $(1998,2009)$. In the face of this, it is far from clear that trying to enforce complete freedom of capital movements is generally optimal. Besides exchange controls, various instruments, (e.g. limits on certain fx positions, taxes on certain forms of international capital flows, differential reserve requirements), are available to national authorities to try to influence such capital flows, with varying degrees of slippage. The climate of opinion has been changing in recent years from steadfast opposition towards, somewhat grudging, acceptance of national controls over short-term capital flows.

But the move in this direction is likely to be limited. One reason for this is that Europe remains adamantly committed to the free movement of capital amongst members of the European Union, despite the role that such capital flows have played in the current crisis there. Indeed it is in the EU, and even more so in the euro-zone, that the conflict, the fault line, between supra-national and national, reaches its most extreme.

The European ideal, that national countries should pool a large part of their sovereign powers in the interests of both European harmony and of broader economic efficiency, is entirely admirable, indeed marvellous in concept. Yet the same countries have not been prepared to go all the way towards a centralised, federal political system with a sizeable central federal budget, nor yet a central system for applying macro and micro-prudential oversight, though the EU is now moving rapidly in this latter direction with the recent establishment of the ESRB, the European Systemic Risk 
Board and the associated three European supervisory boards for banks (EBA), for insurance (EIOPS) and for securities markets (ESMA). ${ }^{2}$

If, (and when), the eurozone can find a way through its current problems, this may give the rest of the world some guidance whether a middle way can be found between supra-national (global) political and legal systems, (which may have some attractive features but are politically unacceptable), on the one hand and local, national control on the other, (practical but sub-optimal and inefficient), (see Trichet, 2011).

The initial analysis, in Europe at least, of the potential problems for such a middle way, as in the eurozone, was faulty. It focussed unduly on public sector indebtedness, the (in)famous Maastricht criteria, ignoring the fact that private sector indebtedness could be just as corrosive, notably when the funds are used either for immediate consumption or for investment purposes, e.g. housing, that would not generate future receipts to pay off the debt. A problem is that the distinction between a sustainable accumulation of debt, whether public or private, and an unsustainable one is not easy to make, and, as always, subject to interpretation.

Moreover, a national boom, with local expenditures greater than local output, financed by debt accumulation from abroad, i.e. current account deficits, is normally accompanied by a relative worsening of unit labour costs, relative to its trading partners. Indeed, that is part of the standard adjustment process. The problem, however, is that, should that boom come to a sudden end, there needs to be a rapid re-alignment of relative unit labour costs, especially in the previous boom country, in order to promote adjustment. This is a key role for flexible exchange rates. When exchange rates are fixed, as in the eurozone, the problem becomes far harder. A gradual

\footnotetext{
2 As Rosa Lastra puts it, (in private correspondence), "The non-exclusive transfer of sovereign powers from the national to the supra-national arena (monetary yes, fiscal no) has resulted in what constitutional law experts would refer as a dynamic system between centralization and decentralization. And experience shows that those systems evolve, often gravitating towards the centre."
} 
adjustment downwards in wages/prices in the deficit countries raises real interest rates there and can set off a debt/deflation spiral. A quick, sizeable, generalised, fair, common reduction in all forms of remuneration, e.g. wages, salaries, pensions, etc., can be achieved in small cohesive countries, e.g. Singapore, Latvia, and to some large extent in Ireland. Whether the same (politico-economic) response (a quick internal devaluation) can be carried out in larger, more complex, more politically divided countries remains to be seen.

One of the pervasive problems of global (or regional) macro-economic adjustment is that the onus to undertake such adjustment falls asymmetrically, and almost entirely, on the deficit, indebted country, at least when it has borrowed in a foreign currency. The deficit country then has to adjust. When concerns about its ability/willingness to repay debts occur, it either has to reduce its deficit rapidly to zero, or to convince potential lenders that it can/will repay, or seek external assistance from the IMF, or a regional fund such as the EFSF, (while it carries out an adjustment process). Moreover there is a knife-edge, tipping problem. Rising concerns about potential default raise the interest rate that the deficit country has to pay in the market for, either new or roll-over, funds, which in turn raises the likelihood of default.

When a country has accumulated debts to the rest of the world in its own currency, it has another option, of inflating those (nominal) debts away. That also can be painful, notably to domestic creditors, and disruptive to economic management. Inflation is another form of default. The choice between debt restructuring and inflation, even when the latter is an option, will not necessarily always come down consciously on the side of choosing generalised inflation.

In the meantime the surplus countries are under much less pressure to adjust. Apart from concerns about currency manipulation and covert barriers to imports, they are, almost by definition, virtuous, competitive with low relative unit labour costs, with high savings and less local expenditure than 
output. How can one criticise success; apart perhaps from noting that the capital transfers to the deficit countries could in many/most cases have been used more productively at home.

Keynes, notably in his plans for the post-World-War-II international financial architecture (1941), was worried about the bias towards world-wide deflation that this asymmetry introduced, also see Kregel (2010). Despite Keynes' attempt to introduce a more symmetric system being thwarted by the main creditor country at the time, i.e. the USA, world history since 1945 has been characterised by inflation, not deflation. This was, however, more the result of poor analysis and policy in the attempt to control inflation rather than a conscious desire to lower high post-war debt ratios by maintaining high inflation, with low, or negative, real interest rates.

But now that macro-economists and policy-makers have seemed to have become more adept at achieving low and stable inflation targets, the 'great moderation', so that surplus countries can hold inflation to around, say, $2 \%$, will that mean that the asymmetric deflationary adjustment bias in deficit countries, allied with the zero nominal interest rate bound (ZIRB), will cause more serious debt/deflationary problems in deficit countries? That was the background that led some in the IMF (Blanchard, et al., 2010) to consider whether a revision of generally acceptable inflation targets from $2 \%$ to $4 \%$ might be desirable.

Such a change would have had no obvious benefits for countries which either did not need to adjust (i.e. surplus countries) or could use flexible exchange rates to do so quite rapidly, and also carried with it a danger of weakening the credibility of all such targets. Whether for these, or other reasons, this trial balloon was comprehensively shot down by almost all major Central Banks.

But that still leaves the problem that the macro-economic adjustment process still falls asymmetrically on deficit countries, and in a low inflation context could cause debt/deflation spirals. 
We turn to this problem at greater length next in Section 2. We then revert to discussion of global financial supervision in Section 3.

\section{Macro-economic Adjustment Processes}

A sovereign has the power to tax and to issue (non-interest-bearing) currency, which it can make legal tender for all debts. This power is subject to the assent of the people and can be overturned by revolution or defeat in war. A subsidiary sovereign has a (possibly limited) power to tax, but cannot issue its own currency. It has to borrow in currencies issued by some other sovereign.

Non-sovereigns can borrow in the currency of their own sovereign, or another. In the latter case they run an additional foreign exchange ( $\mathrm{fx}$ ) risk. Otherwise they either repay by running surpluses of receipts over out-goings, or default and restructure. Subsidiary sovereigns normally borrow only in the currency of their own sovereign, but can (sometimes) borrow in the currency of another. They have to accept, as exogenously determined, the average rate of inflation in the country as a whole. They too can either repay debt, by raising taxes relative to expenditures, or can default and restructure. In addition both non-sovereigns and subsidiary sovereigns, when in trouble, may look to the sovereign for financial support, subsidies and bail-outs. As already noted, the sovereign has the additional power of command over the printing press, and can therefore also inflate away the real weight of nominal debt. While this latter has quite often happened in practice, it has rarely been consciously chosen as a policy, or at least publicly espoused as such, perhaps in part because of the reputational consequences to the government in office which adopted such a policy.

By this definition, of course, both Portugal and Illinois, Spain and California, are similarly subsidiary sovereigns. What then are the main points of difference between the US states and the European eurozone states? First, a much higher proportion of taxes and expenditures flows through the 
federal centre in the USA, so the failure of a US state would be both less cataclysmic and less likely in the USA, though individual states there remain responsible for essential activities, such as law and order, health and education. Second, region-wide integration of financial services is much more complete in the USA than in the eurozone. Most financial services in the USA, e.g. banking, securities markets and insurance, are provided now by nation-wide institutions, whose holdings of state bonds are diversified. The failure of California might bring down some smaller local intermediaries, but it should not cripple the larger American financial intermediaries. By contrast, most banks, insurance companies, etc., in Ireland are Irish. The financial systems and the eurozone states within the EU are intertwined to a degree that is just not so in the USA.

A failure of a euro-state subsidiary government would, for sure, imperil the solvency of its own financial system, (as effectively occurred in Argentina). Equivalently the systemic failure of local financial intermediaries can imperil the economic well-being of the state, whether fully sovereign or subsidiary. The need to prevent economic collapse, with its own implications for government finances, thus has led governments to support their own financial systems, whether by injection of government funds or by guarantees. So within Europe, there is a complex inter-linkage between state and financial system problems that is not present, or to anything like the same extent amongst the subsidiary states of the USA. The eurozone periphery needs to resolve a joint sovereign/financial system problem, rather than the simpler problem in the USA. We shall consider how this may be done later in this Section.

As already emphasised in Section 1, we live, still, in a Westphalian system, in which outside interference by one sovereign in the internal affairs of another is not allowed, except under very unusual or extraordinary circumstances, (an example being the disputed election in the Ivory Coast). So, as a general matter, no other national power, or international collective of nation states such as 
the International Monetary Fund, has the ability to intervene, or to give economic directives, until the nation state in question has formally requested help.

The circumstances in which states ask for such help were in the past in order to provide foreign exchange reserves, so as, usually, to maintain a pegged exchange rate. Even with floating rates, short-term inelasticities and debts accumulated in foreign currencies could cause sovereigns to have an urgent need for foreign exchange. The involvement of the IMF with Greece and Ireland has been on a different plane altogether; one can hardly claim that these countries needed euros, since this was their own currency, (does Illinois need US dollars?). Why did the EU sovereign, (and quite what is the EU sovereign? The ECB, the European Parliament, the EU President, the Head of the EC?), accept the IMF into its internal affairs? Perhaps a combination of reputational concerns, having the IMF rather than the EU (or Germany) administer the unpleasant medicine, of IMF competence in designing coherent rescue plans, and a shortage of funding to be made available for support within Europe, that is the unwillingness to accept a 'transfer union' within Germany, have been, I believe, the main factors.

But it has, in some ways, moved the position of the IMF a further step forward. Rather than just providing foreign exchange funds for the resolution of balance of payments difficulties, the Fund has now been made a party to the attempt to resolve over-indebtedness, irrespective of the currency of the debt, or even of the sovereign status of the country. In a sense this is not new. The excessive accumulation of debt to the rest of the world, the summation of current account deficits, has been a regular precursor of balance of payments and financial crises. The Fund has commonly issued warnings about such developments in its Article IV Reports.

As was, however, highlighted in the recent Expert Review of the Fund's role in the crisis, the Fund has been constrained in 'talking truth to power', both by analytical uncertainties and by the ability of 
the nation states to enforce a dilution of the language involved, the more so the more powerful the nation state. Even in the case of Iceland, the Fund pulled its punches. And there always remains uncertainty whether debt accumulation is sustainable, or not.

So where do we go from here? The most common proposal, usually raised by deficit countries, is that there should be some presumptive indicators of macro-economic imbalance, that should be symmetric for both surplus and deficit countries. Geithner's suggestion, put forward at the G20 Seoul meeting, that a current account deficit/surplus greater than $4 \%$ of GDP should serve as such an indicator is a prime example. The recent Paris G-20 meeting also searched for an agreement on such indicators.

There are several problems with this approach. First, the scale of a current account deficit/surplus cannot be more than an indicator, since its sustainability depends on context. Surpluses greater than $4 \%$ were regularly run by France and the UK in the $19^{\text {th }}$ century, and equivalently deficits greater than $4 \%$ were run by the newly-opening countries such as Australia and Canada, less so in the USA, see below. The sustainability of deficits depends on the probability of repayment; deficit countries will claim that repayment can and will be made. Almost by definition, surplus countries must believe that they will be repaid; otherwise they would not have provided such capital transfers. 
Figure 2
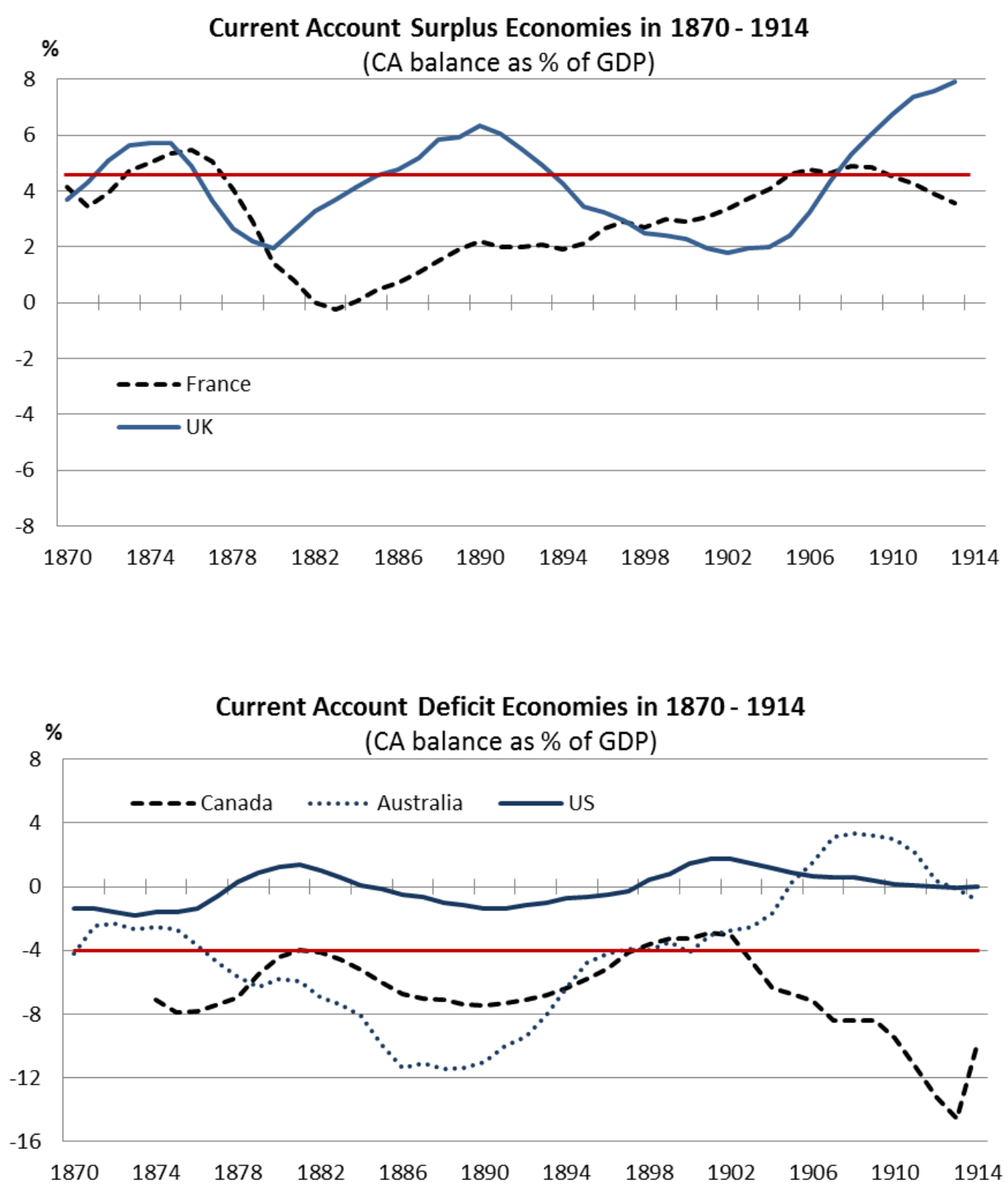

Sources and Datanotes:

To calculate current account balances as percentage of GDP, 5 year moving averages of current account balance values and 5 year moving averages of nominal GDP values (GDP at current prices) have been calculated and used (1866-1870 to 1910-1914). This was done mainly for the consistency of the data illustrated, as only 5 year moving average data were available for the estimates of Canadian current account balances for the period 1868 to 1902 .

France

Source of GDP and current account data :

B. R. Mitchell, (2007), 'International Historical Statistics - Europe, 1750-2005', 6th, Palgrave Macmillan, pp. 1009-1013, and 1049-1045.

$\underline{\mathrm{UK}}$

Source of GDP and current account data: B. R. Mitchell, (1988), 'British Historical Statistics', Cambridge University Press : pp. 831-833, and 869-872. 
Canada

Source of GDP data : Global Financial Data

Bank of Canada

Source of current account data for 1900-1914: B. R. Mitchell, (2007), 'International Historical Statistics - The Americas, 1750-2005', 6th, Palgrave Macmillan, pp. 840 - 841.

Source of 5 year moving average current account data for 1868-1872 to 1898-1902: Penelope Hartland, (1960), 'Canadian balance of payments since 1868', in The conference on research in income and wealth, Trends in the American Economy in the Nineteenth Century, National Bureau of Economic Research : pp. 717-756.

Australia

Source of GDP and current account data: Wray Vamplew ed, (1987), 'Australians : Historical statistics', Fairfax, Syme \& Weldon Associates : p. 131, p. 133, p. 185 , p. 191

US

Source of GDP and current account data: S. B. Carter et al, eds, (2006), 'Historical statistics of the United States : earliest times to the present', Millennial ed, Cambridge University Press : Vol. 3, pp. 23-26, and Vol. 5, pp. 452-461.

Again almost be definition, concern over macro-economic imbalances implies that, given an assumption of continuing current macro-policies, the probability that current creditor claims will not be repaid is higher than the market appears to think, see for example Schumacher, et al., (2011). If such concerns do become justified, deficit countries have to adjust and/or to default, with, or without, the assistance of the IMF.

Meanwhile surplus countries are not forced to take any action themselves, and there is little leverage that the Fund, or anyone else, can impose on them. If the debt of the deficit country is denominated in its own currency, it could in principle threaten to inflate such debt away; and the Chinese are suggesting that this is a covert purpose of the Fed's credit easing. But unless such debt was primarily held by foreigners, and even then, this would amount to cutting off one's nose to spite one's face. So, surplus countries will stand on the sidelines, taking little action simply as a result of such surpluses, and loudly demand a full adjustment by deficit countries, all the time warning of how awful for the deficit country will be the consequence of any default/restructuring, rather than adjustment/repayment.

There is little pressure that the Fund, or anyone else, can currently place on such surplus countries. Small surplus countries could, perhaps, be bullied by the global community, but by the same token 
the effect of an adjustment by them on the international pattern of imbalances would be small. With big countries, such as China, or Germany within the eurozone, the international community is pretty much limited to the argument that more domestic consumption (less saving) now would improve these countries' own inter-temporal welfare, i.e. that reducing their surplus would be of benefit to themselves. In so far as this argument fails to sway the surplus countries, there seems, at present, little more that can be done to persuade the surplus countries to alter direction. Or is there something more?

I argued earlier that the sustainability of debt/deficits depended on the probability of default/repayment, and that the worst problems/crises arose when the market switched suddenly from an excessive belief that such repayment was assured to (possibly excessive) belief that such repayment was doubtful, with a significant chance of default/restructuring. It is, perhaps, in this context that the IMF could play a larger role. Clearly it is in surplus countries' self-interest to press for adjustment/repayment rather than restructuring. It is not so clear that this is the appropriate balance for the IMF. Restructuring places part of the weight of loss on surplus countries. If surplus countries knew that, beyond an appropriate degree of adjustment (how measured?) the Fund would advocate, facilitate and help to finance a process of restructuring debt in deficit countries, then they might have been more cautious about their prior capital transfers.

The Fund's raison d'etre has largely been to encourage adjustment, and to avoid insolvency, default and restructuring. Perhaps it has gone too far in this direction. In so far as some of the problem of economic imbalances is due to the policies of surplus countries, this raises the question of how such countries might share some of the burden when macro-economic problems then arise. There might be several answers to this question, an assessment which would take us beyond the scope of this paper. 
But if the Fund is to support such restructuring, placing more of the cost on surplus countries, these countries could reasonably argue, in turn, that they would need more forewarning of the Fund's viewpoint. What this might superficially suggest is that the Fund should enter into the business of giving credit ratings to sovereign and sub-sovereign entities. But could/would the Fund be able to do so? Suppose that the Fund attempted to downgrade the credit rating of the USA! The US could withhold its subscription and/or use its blocking power on the Board to prevent this happening. Can the Fund stand up independently of its own member major nations?

Probably not. Perhaps all that the Fund can do is to provide countervailing support to the credit ratings agencies when they are imposing down-grades to the credit ratings of major nation states, against the huge, and inappropriate, pressures that such nation states will apply on the CRAs not to do so, including threats of regulatory arm-twisting. One possibility would be to enforce a comply, or explain, procedure to credit ratings. Thus, for example, no country with a current account deficit greater than $\mathrm{X} \%$, and/or a public sector deficit greater than $\mathrm{Y} \%$, could have a credit rating greater than Z, unless it provided a clear, and persuasive, plan for the elimination of such deficits.

So, within this framework, the potentiality of any sovereign choosing to default and to restructure, even when the debts are in the sovereign's own currency, is acknowledged. A sovereign with an unsustainable debt in its own currency (Japan?) could quite possibly prefer to restructure (partially) rather than either inflate or to load its citizens with burdensome taxes. So by the same token the risk weighting of all sovereigns cannot be zero. Perhaps the risk-weighting for sovereign debt held by financial intermediaries of that same country might still be zero, on the grounds that the health of a country's financial system and of its own sovereign are so closely inter-woven that any government would have to support its own systemic financial intermediaries, even when it was defaulting and restructuring against all other holders. 
The idea that sovereign debt is riskless, let alone sub-sovereign debt, has become unrealistic.

Instead, what is being suggested here is that sovereign debt credit ratings, and alongside that risk-

weightings for the purpose of CARs, should be adjusted presumptively in the light of a number of key

indicators, including both flow and stock variables, and relating to both public, financial and to non-

financial entities. Of course, this would only be a presumption; the role of the IMF could be as a

neutral arbiter ${ }^{3}$ to examine each nation state's case, as would inevitably be pushed, why the

presumption should not be applied in their own case. Unless the nation in question could persuade

the IMF to support a positive exception in its own instance, the presumption would remain.

The purpose of the exercise would be to raise the risk premium involved in the process of capital

transfers from surplus countries to deficit countries, as the position of the latter verges increasingly

on being unsustainable, and to give surplus countries additional forewarning that, beyond some

appropriate measures of adjustment by deficit countries, the IMF would be prepared to advocate a

degree of burden-sharing, via orderly restructuring.

The basic point being made is very simple. Neither the Fund, nor the global community, has any

locus or leverage for putting external pressure on surplus countries to reduce their current account

surplus, or net national savings surpluses. But, when such imbalances/savings surpluses are

dangerous is when they allow/encourage deficit countries to run up unsustainable debt positions.

3 Rosa Lastra has told me that

"A similar idea has been mentioned in the past by Walter Robicheck, advisor to the IMF Managing Director from 1982 to 1984, by Lee Buchheit, by Arminio Fraga and by Rosa Lastra. In Chapter 14 of Lastra's Legal Foundations of International Monetary Stability (OUP, 2006) she discusses how the IMF could develop an internal rating system for countries' banking and financial systems akin to the CAMEL system in the USA. IMF composite ratings could be based upon the results of Article IV consultations, FSAP reports, FSSAs and ROSCs, and upon the data compiled by members in accordance with the Special Data Dissemination Standard or SDDS and the General Data Dissemination System or GDDS. Arminio Fraga wrote in 1996 that the IMF should act as 'the permanent auditor of countries, which should voluntarily submit themselves to examination in order to lower their borrowing costs. Annual Article IV consultations could be supplemented by quarterly reviews that would enhance the credibility of the data released under the IMF's recent initiative [he referred to the Special Data Dissemination Standard] and thus help to reduce the costs of adjustment programs'." 
Where the Fund, and the global community, could get a real purchase on such developments is to underscore just how risky such net capital transfers then really are, both ex ante by ensuring that credit ratings and risk weights for CARs do actually reflect those real risks and ex post by supporting debt restructuring in those cases where internal adjustment would go too far in pushing a debtor into a debt/deflation spiral, (or into a devaluation/inflation spiral). The Fund should be reviewing the theory of optimal international burden sharing.

And so, of course, should the European authorities. Indeed, the problems of macro-economic imbalances, excessive cross-border capital flows, insufficient appreciation of sovereign/financial risk, and the need for some analysis of optimal burden sharing, have been even more acute in the eurozone, than in the world at large. Despite brave talk about comprehensive solutions, the eurozone problem has, so far, been treated by emergency patches of liquidity, which simply delays the resolution process. Meanwhile, the bond market, rather than being chided for its prior blind optimism (with Greek bonds playing the role of AAA tranches of CDOs), is currently castigated for a reversion to realism. Where will this end? Who knows? But it is difficult to be optimistic.

Be that as it may, when the issue is the question of how to handle macro-economic imbalances, the main problem has been the fault-line between the global macro/financial system and the Westphalian national power structure. When we come to examining supervision of the global financial system, to which we turn next, the greater problem, perhaps, has been of analytical failure.

\section{Global Financial Supervision: Where next?}

In order to see where we may be going next, it is a good idea to know how we got here in the first place. Let me start with structure. The Basel Committee on Banking Supervision did not see itself 
initially as a body that had the locus, or the ability, to set international rules, principles or codes of conduct. Instead they saw themselves as a like-minded gathering of, mostly European, regulatory officials, exchanging experiences and discussing practices, with a view to recommending best practices and principles to their own Central Bank governors. That changed in 1996 when emerging countries applied to the G-7 for assistance in devising some core principles for the conduct of banking supervision.

Initially the BCBS was hesitant in taking on this task themselves, since it would extend their remit beyond their previous comfort zone. But, when the BCBS realised that the alternative was for the IMF to undertake this exercise, they changed their tune. There was an exchange of letters, and meetings, between Tomasso Padoa-Schioppa, then Chairman of the BCBS, and Manuel Guitan of the IMF, now alas both dead, at which a concordat was agreed, (Goodhart, 2011). The BCBS, now supplemented by the Financial Stability Board (FSB), would propose the format for international regulation, while the IMF, supported by the World Bank, would do the supervisory ground-work, through the FSAP (Financial System Assessment Procedure). In the European context the European Systemic Risk Board may, equivalently, establish some over-arching macro-prudential principles, leaving it to national authorities to do the detailed supervision. On the whole the division of responsibilities between the BCBS/FSB as the regulatory body and the IMF/WB as the supervisory arm has worked, in my view, rather well. There is no basis for changing this general structure.

There is much less reason to be content about the content/substance of international regulation/supervision. Again how did we get here? The catalyst was the fragility (of capital buffers) of the major city-centre US banks in the face of the MAB (Mexican/Argentine/Brazilian) LDC (less developed country) crisis of 1982 . Congress wanted to enforce higher CARs unilaterally on US banks; but the US banking industry successfully argued that this would just divert financial business to (even less well capitalised) Japanese and European banks - the 'level-playing-field' gambit - , so Volcker 
was mandated to go to the BCBS and get an agreement, by all the major countries, for a common, higher, accord on CARs.

After difficult, and quite protracted, negotiations, described in Goodhart (2011) and Solomon (1995), this resulted in the Basel I Accord (1988). No part of this Accord was influenced by inputs from economics and economists, not that they had, at least at that time, much to offer, since the analysis of financial frictions, and their interaction with the real economy was then in its infancy and has only had a stunted growth since then.

Be that as it may, there were numerous serious shortcomings with Basel I, and these were not rectified, indeed in one respect worsened, under Basel II. I shall review three such lacunae here. First, the BCBS had no formal legislative role; it saw its function as no more than making generalised recommendations to their own national Central Bank governors. Hence they felt unable to discuss penalties, or sanctions, for any transgression of their proposed ratios, with the application of legal sanctions being the prerogative of each separate Westphalian nation state independently. So the CARs that they did propose, i.e. $4 \%$ of RWA for Tier $1,8 \%$ of RWA for Tier 2 , became treated as required minima, which could not be encroached without severe reputational cost. But, as minima, they became unavailable for loss absorption. Instead, what became the true buffer was the much more exiguous excess margin of capital above the required minima.

As Martin Hellwig has noted $(2009,2010)$, bank capital plays several roles, e.g. loss absorption, skinin-the-game, leverage limitation, and economists have made little headway in assessing what ratios might be optimal for any of these various purposes, or on the relative costs of raising such ratios; for exercises in the latter see Miles, et al. (2011), Admati et al., (2011). What we do know is that as equity capital is eroded, at least amongst SIFIs, the potential risks of systemic externalities increase. This would suggest, to me at least, having a much higher estimate of 'a fully satisfactory' level of 
equity capital, and then working out, much more carefully, a gradual, and graduated, ladder of sanctions/penalties as equity capital declines below its 'fully satisfactory' level to a point at which prompt corrective action (p.c.a.) becomes mandatory.

In some part the gap between the higher 'fully satisfactory' level of equity capital, that many finance economists would like to see, and the level that the industry is prepared to tolerate, may be met by a growing use of contingent convertible ( $\mathrm{CoCo}$ ) bonds, or by pre-negotiated or statutory bail-in requirements for various categories of bonds, whereby supported by Collective Action Clauses (CACs) such instruments may become transmuted into additional equity. The triggers, transfer terms and pricing arrangements, will be somewhat complex and the implications for new fund raising in the midst of a contagious crisis are worrying. Nevertheless this is a direction in which, in Europe at least, policy appears to be moving.

The BCBS/FSB has made a first, initial step in the direction of imposing a ladder of sanctions, with any decline of tier 1 core equity below 7\% reinforced by constraints on dividends and remuneration, until it reaches the p.c.a. point of $4.5 \%$. No doubt, 'c'est le premier pas qui coute', but much more needs to be done to extend and to refine a graduated ladder of sanctions, (as was first attempted in the FDIC Improvement Act of 1991), and also to study how such regulation can be manipulated and avoided, (e.g. by the artificial creation of equity capital, such as lending to an agent who uses the funds to buy back equity, perhaps in a concert party arrangement).

Whereas constraints on dividends and/or remuneration have a valid, and major, role to play in any such ladders of sanctions, an alternative instrument could be Pigovian taxes, see Masciandaro and Passarelli (2011). The use of taxation to discourage activities with negative externalities has rarely been used, or even considered, in banking or finance, no doubt for several reasons, such as the difficulty of assessing an intermediary's contribution to systemic risk, that the tax would bite more 
the weaker the intermediary, and the steadfast opposition of the industry. Nevertheless bank/finance industry taxation has now been put on the agenda, following Obama's espousal of such a proposal in early 2010 (N.Y. Times, January 14, 2010). Rather than using such a tax in an ex ante fashion to influence behaviour and to reduce the risk of financial frictions, such taxes have recently more generally been levied to punish banks for paying out high bonuses (UK), to make banks repay ex post the cost of bail-outs (Dodd-Frank), to force banks to pay a 'fair share' of the extra burden of meeting the enhanced public sector deficit/debt, and because such a tax is generally popular, (mitigated only by threats of migration to lower-tax havens). What is needed is a much more comprehensive (holistic?) assessment of how bank taxation might fit within the wider framework of financial regulation. This was discussed at some length at the G7 Finance Minister/Central Bank Governor meeting in Canada in February 2010, but there was no general agreement on the topic. There is a danger that the inter-relationship between such taxation and financial regulation will not receive proper assessment and analysis. Since taxes are fiscal, the $\mathrm{BCBS} / \mathrm{FSB}$ may hesitate to comment; since regulation is for specialist financial authorities, Ministries of Finance may ignore the macro-prudential implications and possibilities of such taxes.

The second main shortcoming of Basel I and II was that it assumed that the risk weighting of any asset could not only be approximately assessed by regulators but was constant over time. Neither is true. Moreover the risk weightings that were adopted were, at least in some large part, politically influenced, notably the zero weighting on OECD government debt, and the relatively low weight on residential mortgages. In particular, the RWs were independent of context and of the changing portfolio structures of the banking/financial system. No attempt then, or since, has been made to adjust the RWs in line with the potentiality for systemic collapse, should that asset category weakens sharply in value. As W. Wagner (2010) and A. Persaud (2000) have shown, the risk to the banking system of a decline in asset prices is a function of how widely and commonly that asset is held 
amongst all banks. Thus weakness in commercial property prices often poses a threat to banks, whereas weakness in equity prices generally does not.

One response to this kind of criticism is to propose putting greater weight on stress tests, as an adjunct to and perhaps a mechanism also for adjusting RWs over time. A problem with this is that such stress tests only examine the exogenous risk of the first-round effect of a shock to asset prices. Of equal concern is the 'endogenous risk' of how bank reactions could amplify the problem, see Brunnermeier and Pedersen (2005, 2009), Danielsson et al. (2001). To focus only on exogenous risk, and to ignore endogenous risk, is to miss out crucial aspects of the overall picture. Had a stress test been run in, say, June 2007, in which banks were asked to assume what would then have appeared an extreme value for a decline in US housing prices, possibly -10 to $-15 \%, I$ am sure that all major US and European banks, on the basis of their best modelling strategies, would have been fully confident of absorbing such a hit confidently. It was the joint switch of financial intermediaries towards selling such assets, and the consequent drying up of liquidity that triggered the crisis. What matters is not so much the action of the individual financial intermediary, but the joint actions of the collection of Fls. You cannot easily assess this by a stress test exercise on individual Fls. What is needed, in addition, is further and better modelling of the financial system as a whole, i.e. top-down systemic modelling exercises to complement the bottom-up stress tests. Such top-down models of the financial system as a whole have barely begun to become available.

The third, and final, shortcoming of the previous Basel Capital accords was that they caused financial regulation, especially in conjunction with mark-to-market accounting, to become even more procyclical. This was particularly so in the case of Basel II. It was a matter of pride for the authors of Basel II that they had aligned regulatory capital more closely with the economic capital that banks want to keep for their own purposes. But, as documented by Adrian and Shin $(2008,2010,2011)$, desired leverage of FIs is procyclical. In a boom, bad debts and n.p.I.s are down, profits and capital 
on a mark-to-market basis are way up, expectations and credit ratings rise. Never did the banking systems of the developed world look stronger (to most observers, including to their regulators), nor were major bank CDS prices lower than in the early summer of 2007.

After a crisis has started, financial regulation is largely otiose. Market pressures, and enhanced risk aversion, will cause Fls to reduce their exposures, to de-lever, often much more than the authorities would like. Indeed in the recent crisis there was often a common attempt by the authorities simultaneously to toughen up on capital/liquidity regulations and at the same juncture to encourage them to extend more loans to the private sector (see many of Tim Congdon's recent papers, notably Standpoint, July 10, 2011). This patent conflict has been mitigated, at least in part, by allowing extraordinarily long lags before such regulations are to be put in place.

Nevertheless the point is quite general. Financial regulation could/should have its major impact in reining back the boom; it has less role in the bust. But by the same token regulation has to operate against the tide of the market, 'to take away the punch bowl just as the party gets going'. This is not going to be a popular exercise. Think of what would have been the pressures on the Fed if it had tried to shut down the sub-prime market in 2005/6! For a Central Bank to oppose the combined ranks of market, politicians, media, lenders and borrowers, (until the crisis sub-prime was a great deal for most such borrowers), is not easy. Under Pillar 2 of Basel II any Central Bank could have raised CARs on their own national banks; none did in the years 2005-7. The Spanish dynamic preprovisioning mechanism was one of the few initiatives in this direction (Saurina, 2009). Again there were several steps, both fiscal and regulatory, that could have been taken to calm an excessively buoyant housing market in several countries. With a few minor exceptions, e.g. Hong Kong, Estonia, no such action was taken. 
The authors of Basel III have now accepted the desirability of counter-cyclical macro-prudential regulation in principle, though the potential add-on for this purpose, at a maximum of $2 \frac{1}{2} \%$, is quite limited. What they have not yet recognised are the obstacles to the activation of counter-cyclical measures in practice. What they have done, under pressure from the Central Bank lobby, is to leave the activation of counter-cyclical measures entirely to the discretion of the individual national Central Bank. Given the uncertainty of whether a boom is sustainable, or not, and the certainty that official steps to check such a boom are likely to be very unpopular, this is a recipe for ensuring that counter-cyclical measures will rarely, if ever, be deployed. Perhaps the European Systemic Risk Board, which is less subject to domestic political pressures, can play a role in recommending the introduction of such counter-cyclical measures.

In Section 2 , on macro-economic imbalances, I argued that there would be substantial benefits to some presumptive indicators of sustainability which might, perhaps, lead to subsequent adjustments to credit ratings. By exactly the same reasoning, there might be some presumptive indicators of unsustainable credit/asset price expansion, which might lead to counter-cyclical macro-prudential measures, again on a comply or explain basis.

I could continue for far too long with the remaining short-comings of Basel III. Despite its weaknesses, it has recognised several of the major weaknesses of Basel II, and has gone some way to rectify them. The glass is half-full.

Nevertheless is also remains half-empty. In the course of discussion of the shortcomings of just three aspects of the Basel regulatory process, I have put the following macro-prudential issues forward for future discussion, as follows:-

1. How to introduce a more graduated ladder of sanctions for transgression of CARs (and liquidity requirements) into the regulatory process. 
2. How to estimate 'fully satisfactory' and p.c.a. minima levels of capital.

3. The use of CoCos and bail-ins.

4. The role, if any, of Pigovian taxes in crisis prevention.

5. Whether to improve, and if so how, the measurement of asset risk, or to abandon the whole concept of risk weightings.

6. The role, if any, of stress tests, and whether these can be complemented by top-down models of the financial system.

7. How to strengthen the authorities' capacity to employ counter-cyclical macro-prudential measures. Can presumptive indicators be found? Can these be used on a 'comply or explain' basis?

8. How to respond in the conduct of macro-prudential regulation to the Lucas critique.

This is not a complete agenda, but it is enough to be getting on with for the time being. 


\section{Bibliography}

Admati, A.R., DeMarzo, P.M., Hellwig, M.F. and P. Pfleiderer, (2011), 'Fallacies, Irrelevant Facts and Myths in the Discussion of Capital Regulation: Why Bank Equity is NOT Expensive', work in progress (March).

Adrian, T. and H. Shin, (2011), 'Financial Intermediaries and Monetary Economics', Chapter 12 in Handbook of Monetary Economics 3A, ed. by B. Friedman and M. Woodford, pp. 601-650, North Holland.

Adrian, T. and H. Shin, (2010), 'The Changing Nature of Financial Intermediation and the Financial Crisis of 2007-09', Federal Reserve Bank of New York Staff Reports, no. 439.

Adrian, T. and H. Shin, (2008), 'Liquidity and Financial Cycles', Bank for International Settlements Working Papers, No. 256.

Agence France Presse, (2008), 'Report on Queen Elizabeth Visit to London School of Economics, AFP, November 5.

Blanchard, O., Dell'Ariccia, G. and P. Mauro, (2010), 'Rethinking Macroeconomic Policy', IMF Staff Position Note, SPN/10/03 (January).

Borio, C., (2007), 'Change and Constancy in the Financial System: Implications for Financial Distress and Policy', Bank for International Settlements Working Paper, No. 237.

Borio, C. and P. Lowe, (2004), 'Assessing the Risk of Banking Crises', Bank for International Settlements Quarterly Review, (Paper 0212), (January).

Borio, C. and P. Lowe, (2003), 'Asset Prices, Financial and Monetary Stability: Exploring the Nexus', Bank for International Settlements Working Paper, No. 114.

Borio, C. and W. White, (2004), 'Whither Monetary and Financial Stability? The Implications of Evolving Policy Regimes', Bank for International Settlements Working Paper, No. 147.

Brunnermeier, M. and L. Pedersen, (2009), 'Market Liquidity and Funding Liquidity', Review of Financial Studies', 22(6), pp 2201-2238.

Brunnermeier, M. and L. Pedersen, (2005), 'Predatory Trading', Journal of Finance, 60(4), pp 18251863.

Calvo, G., (2009), 'Financial Crises and Liquidity Shocks: A Bank Run Perspective', NBER Working Paper, No. 15425, (October).

Calvo, G., (1998), 'Capital Flows and Capital-Market Crises: The Simple Economics of Sudden Stops', Journal of Applied Economics, 1(1), pp 35-54.

Calvo, G., Izquierdoa, A. and L.F. Mejia, (2008), 'Systemic Sudden Stops: The Relevance of Balance Sheet Effects and Financial Integration', NBER Working Paper, No. 14026.

Calvo, G., Izquierdoa, A. and E. Talvi, (2006), 'Sudden Stops and Phoenix Miracles in Emerging Markets', American Economic Review, 96 (2), pp 405-410.

Congdon, T., (2011), 'The Unnecessary Recession', Standpoint, July 10, http://www.standpointmag.co.uk/node/1577/full. 
Danielsson, J., Embrechts, P., Goodhart, C., Keating, C., Muennich, F. and H. Shin, (2001), 'An

Academic Response to Basel II', LSE Financial Markets Group Special Paper no. 130.

Goodhart, C.A.E., (2011), The Basel Committee on Banking Supervision: A History of the Early Years, 1974-1997, (Cambridge: Cambridge University Press), forthcoming.

Hellwig, M.F., (2010), 'Capital Regulation after the Crisis: Business as Usual?', Working Paper Series of the Max Planck Institute for Research on Collective Goods, 2010_31, July.

Hellwig, M.F., (2009), 'Systemic Risk in the Financial Sector: An Analysis of the Subprime-Mortgage Financial Crisis', De Economist, 157, pp 129-207.

Keynes, J.M., (1941), 'Proposals for an International Currency Union', in D. Moggridge, ed., The Collected Writings of John Maynard Keynes, Vol. 25, pp 69-94, (Cambridge: Cambridge University Press).

Kregel, J., (2010), 'An Alternative Perspective on Global Imbalances and International Reserve Currencies', Levy Institute, Public Policy Brief No. 116, (October).

Lastra, R., (2006), Legal Foundations of International Monetary Stability, Oxford University Press.

Masciandaro, D. and F. Passarelli, (2011), 'Financial Systemic Risk: Taxation or Regulation?', Paolo Baffi Centre Research Paper Series No. 2011-91, (May).

Miles, D., Yang, J. and G. Marcheggiano, (2011), 'Optimal Bank Capital', Bank of England, External MPC Unit, Discussion Paper No. 31, (January).

New York Times, (J. Calmes), (2010), 'Taxing Banks for the Bailout', New York Times, January 14, http://www.nytimes.com/2010/01/15/us/15tax.html.

Persaud, A., (2000), 'Sending the Herd off the Cliff Edge: The Disturbing Interaction between Herding and Market-Sensitive Risk Management Practices', The Journal of Risk Finance, 2(1), pp 59-65.

Rajan, R., (2006), 'Has Finance made the World Riskier?', European Financial Management, 12(4), pp 499-533, (September).

Rajan, R., (2005), 'Has Financial Development Made the World Riskier?', Proceedings of the Jackson Hole Conference organized by the Kansas City Fed, pp 313-369.

Saurina, J., (2009), 'Dynamic Provisioning: The Experience of Spain', The World Bank Group, Crisis Response: Public Policy for the Private Sector, Note No. 7, July, http://rru.worldbank.org/PublicPolicyJournal.

Schumacher, D., Garzarelli, F., and B. Broadbent, (2011), European Weekly Analyst, Goldman Sachs, (March 3).

Solomon, S., (1995), The Confidence Game: How Unelected Central Bankers are Governing the Changed Global Economy, (New York: Simon \& Schuster).

Trichet, J.C., (2011), 'Building Europe, Building Institutions', http://www.ecb.int/press/key/speaker/pres/html/index.en.html.

Wagner, W.B., (2010), 'Diversification at Financial Institutions and Systemic Crises', Journal of Financial Intermediation, 19(3), pp 373-386, July. 
White, W., (2006), 'Procyclicality in the Financial System: Do We Need a New Macrofinancial Stabilisation Framework?', Bank for International Settlements Working Paper, No. 193.

White, W., (2004), 'Are Changes in Financial Structure Extending Safety Nets?', Bank for International Settlements Working Paper, No. 145. 